\title{
The Arctic and Africa in China's Foreign Policy: How Different Are They and What Does This Tell Us?
}

\author{
Christer Pursiainen \\ UiT The Arctic University of Norway
}

\author{
Chris Alden \\ London School of Economics \\ Rasmus Bertelsen \\ UiT The Arctic University of Norway
}

\begin{abstract}
The article discusses China's policies in and towards the Arctic and Africa within a comparative perspective. To what extent is China's policy adaptable to different conditions? What does this adaptability tell us about China's ascendant great-power role in the world in general? What is the message to the Arctic and Africa respectively? The article concludes that China's regional strategies aptly reflect the overall grand strategy of a country that is slowly but surely aiming at taking on the role of leading global superpower. In doing so, Chinese foreign policy has demonstrated flexibility and adaptive tactics, through a careful tailoring of its so-called core interests and foreign policy principles, and even identity politics, to regional conditions. This implies that regions seeking autonomy in the context of great power activism and contestation should develop their own strategies not only for benefiting from Chinese investment but also in terms of managing dependency on China and in relation to China and great power competition.
\end{abstract}

Keywords: China-Arctic, China-Africa, geoeconomics, geopolitics, regional regimes, China's sub-global identities, China's roles

Responsible Editor: Øyvind Ravna, Faculty of Law, UiT The Arctic University of Norway

Received: June 2020; Accepted: November 2020; Published: February 2021

\footnotetext{
^Correspondence to: Christer Pursiainen, email: christer.h.pursiainen@uit.no

(C) 2021 Christer Pursiainen, Chris Alden and Rasmus Bertelsen. This is an Open Access article distributed under the terms of the Creative Commons Attribution-NonCommercial 4.0 International License (https://creativecommons.org/licenses/ by-nc/4.0/), allowing third parties to share their work (copy, distribute, transmit) and to adapt it, under the condition that the authors are given credit, that the work is not used for commercial purposes, and that in the event of reuse or distribution, the terms of this license are made clear.

Citation: Christer Pursiainen, Chris Alden and Rasmus Bertelsen. "The Arctic and Africa in China's Foreign Policy: How Different Are They and What Does This Tell Us?" Arctic Review on Law and Politics, Vol. 12, 2021, pp. 31-55. 


\section{Christer Pursiainen, Chris Alden and Rasmus Bertelsen}

\section{Introduction}

While regions such as the Arctic or Africa are important subjects of international politics in their own right, sometimes to understand the challenges they face it is appropriate to consider such regions in the context of, or even as targets of, much larger global developments and drivers. One of these challenges is without doubt the gradual but steady rise of China into the role of global superpower, which is key to understanding the current and future roles of the Arctic and Africa in a broader perspective.

The conduct of China's foreign policy has been a subject of controversial political and academic debate for over two decades. Is China purposefully challenging the current global order, and will it eventually use its successful authoritarian state capitalism to seek to shape the whole world in its image? ${ }^{1}$ Or is it a question of an ascendant but benevolent great-power's adaptation to the prevailing system, a country striving to find its global role in a win-win fashion, as China itself claims? ${ }^{2}$ Or perhaps China's grand strategy is based on a nationalist urge to re-establish the country's strength and become a world power, while being particularly sensitive to domestic threats of disorder and foreign interference? ${ }^{3}$

By focusing our discussion on the Arctic and Africa, we believe we are not only able to contribute to debates on China's rise in the global arena, but also able to draw a much more nuanced picture of this transition than is usual in this context. While the two regions chosen could have been replaced by many more, say, Europe, Latin America, or the Middle East, we believe the Arctic and Africa reflect illustrative cases of what we call Chinese "sub-global" policies, allowing us to identify the important causal drivers of China's foreign policy in different contexts. Does China's policy in and towards these two regions reflect a grand strategy, or does it consist of a set of improvised regional foreign policy strategies without any common denominators? What are the differences and similarities of the Arctic and Africa from the Chinese perspective?

In addressing the above questions, we draw together some basic concepts of international politics: geoeconomics and geopolitics; regimes and governance; identities and roles. While not immersing ourselves in the inter-school International Relations (IR) debates, these three broad perspectives represent heuristic angles that enable us to systematise the intertwined empirical issues for our comparative purposes.

Through the application of these concepts - in the spirit of analytic eclecticism ${ }^{4}-$ to Chinese policies towards the Arctic and Africa, our approach becomes somewhat more nuanced than the initial questions presuppose. In a sense, they tell three intertwined stories instead of one, and when brought together, they provide a holistic comparative frame for understanding and explaining China's policies in these two increasingly important regions. Beside the empirical differences of these regions and Chinese politics towards them, with our theoretical perspectives we can identify the 
deeper logic in China's behaviour, which, as we argue, shows a high degree of adaptive capability in different contexts.

By the same token, we will also highlight factors that seem to be essential for individual regions and countries in their dealings with a rising great power whose entrance, not only to the global arena, but also to regions far from its mainland, puts pressure on existing regional and national rules and practices.

\section{Geoeconomics and geopolitics}

The most obvious starting point to study Chinese foreign policy in global and regional settings is to approach it in terms of great power competition, emphasising rival interests and relative gains rather than cooperation. This means that any assertion of global strategic intent by China must be weighed against the hegemonic position of the U.S., ${ }^{5}$ whose reach extends in geographic terms on a truly global scale and, however contested, continues to wield enormous international structural power. ${ }^{6}$ While some argue that, barring the onset of a "system-making moment", U.S. structural power is likely to endure for the foreseeable future, ${ }^{7}$ others demur that the country's decline is manifesting to different and possibly accelerating degrees across dimensions of structural power in the international system. ${ }^{8}$

From this power politics perspective, geoeconomics ${ }^{9}$ and geopolitics ${ }^{10}$ are two appropriate disciplines to consider when examining China's policies in the Arctic and Africa from an interest and structural power politics perspective. China's Beltand-Road-Initiative (BRI) especially goes far beyond economics and shapes the country's use of power and influence in the international system. ${ }^{11}$ Geopolitics in turn can be seen as a primitive (and earlier) version of realism, which focuses in particular on great-power rivalries over geographic areas, including the military strategic dimension.

What then are the drivers of China's geoeconomic and geopolitical interests in the Arctic and Africa respectively, and why have they emerged? How is this manifested in practice, and what kinds of strategies are used to advance these interests?

\section{The Arctic}

The Arctic has become more important than ever due to the effects of climate change, which have in turn opened up the possibility to extract oil, gas and mineral resources hitherto inaccessible. Also, a mostly Russia-controlled shipping route between Europe and Asia will be more usable due to the fact that it is considerably shorter than routes used presently. It is little wonder then that China has also started to pay attention to this area, formulating its strategic interests in its Arctic White Paper published in 2018. ${ }^{12}$

The so-called core interests of China and its Communist Party, formally declared in $2011,{ }^{13}$ represent the country's generic national interests. They are the red lines 


\section{Christer Pursiainen, Chris Alden and Rasmus Bertelsen}

of Chinese policy, both in the domestic and foreign policy domains. While the scope of the core interests seem to be fuzzy, evolving and gradually broadening, ${ }^{14}$ they emphasise the need for overall internal social stability. To this end, it is necessary to ensure the sustainable economic and social development that forms the basis of the continued legitimacy of the Communist Party. This in turn presupposes growing economic power internationally.

China is the world's second-largest, and soon-to-be largest, economy. It is the world's biggest importer of energy and raw materials, and is the largest trading country in the world. This trade overwhelmingly travels by sea. Securing and strengthening Chinese international trade is paramount to the above-mentioned main core interest.

So where does the Arctic fit into all this? In China's Arctic White Paper, ${ }^{15}$ geoeconomic interests are presented under the title "Utilising Arctic Resources in a Lawful and Rational Manner". These include four areas: participation in the development of Arctic shipping routes; the exploitation of oil, gas, mineral and other non-living resources; conservation and utilisation of fisheries and other living resources; and developing tourism resources.

While Chinese investments have been and to some extent continue to be welcome, from the Arctic countries' perspective, the main concerns in turn have been the perceived Chinese economic and political influence gained through investments, the environmental policy of China, and the social performance related to Chinese companies. ${ }^{16}$ What then is the reality? The New York Times wrote in 2019 that "China is trying to pour money into nearly every Arctic country", describing the Arctic as "Latest Arena for China's Global Ambitions", ${ }^{17}$ but the concrete success stories are not very visible. True, several efforts have been - and continue to be - made by Chinese companies to invest in land, mining licenses, tourism, or Arctic science in Greenland, Northeast Iceland, Northern Norway, Finland, Sweden and less so Canada and Alaska. ${ }^{18} \mathrm{~A}$ closer look at these reveals that it is more often a question of exactly ambitions and tentative plans, perhaps some mining projects and scientific cooperative centres, than any large-scale agreed-upon infrastructure projects. Except in one country - Russia.

Thus, China's main interest lies in the Russian Arctic and Far Eastern oil and natural gas resources, and the infrastructure that supports their transportation to China. With energy security being a major concern for China, which currently imports vast quantities across sea lanes controlled by the U.S. Navy, it is logical that the Sino-Russian energy partnership is deepening rapidly. The Northern Sea Route is a promising seaway for Chinese seaborne trade, which China has already been "actively testing"19 for several years. Hence, Russian-Eurasian and Chinese BRI geoeconomic designs are merging, where the Northern Sea Route may become the Polar/Ice Silk Road, despite mutual Sino-Russian suspicions and the increasingly unequal relationship between the two. To this effect, it has been argued that "China is aware of the strategic importance Russia attaches to the Arctic, and Beijing has reassured Moscow that it does not seek to challenge Russian interests in the region". ${ }^{20}$ 
The above is closely related to enormous Chinese investments in Russian Arctic and Far East energy production and transportation infrastructure, as well as longterm sales agreements. ${ }^{21}$ The biggest investments in the Arctic thus far are related to Russia's Arctic gas liquefaction projects, especially the Yamal LNG, and related gas pipeline projects that connect the Russian Arctic/Siberia and China, of which the first stage of development has already been implemented, while further stages have been agreed upon. Indeed, it is argued that of all the Arctic countries, Russia has shown the greatest commitment to the development of the region and has the greatest potential for cooperation with China. ${ }^{22}$

Traditional geopolitics is the other side of the coin, and closely related to hard security. China does not border the Arctic, and none of the "core interest" sensitive regions and sea spaces under dispute between China and neighbouring countries are in or near the Arctic. However, there are indirect Arctic security aspects related to its core interests. ${ }^{23}$

The issue at stake obviously concerns the heightening superpower competition between the potentially declining U.S. and rising Chinese powers. The Arctic military dimension to Sino-American security relations is primarily in the domain of the nuclear strategic balance. The Arctic region is the shortest flightpath for intercontinental ballistic missiles (ICBMs) and long-range bombers between Eurasia and North America. Hence, while the Arctic continues to play a key role in the strategic balance between the U.S. and Russia (historically the USSR), the same goes for the Sino-American nuclear strategic balance. The Cold War early warning radar Cobra Dane in the Alaskan Aleutian Islands historically covered the Soviet Far East, but also covers large parts of East Asia. Missile defence interceptor missiles that can shoot down ICBMs - allegedly from North Korea - are based at Fort Greely near Fairbanks, Alaska.

According to U.S. military speculations, China might want to operate its emerging submarine-based nuclear deterrent in the Arctic Ocean, where it can benefit both from sea ice cover and short distances to North America. The U.S. Department of Defense 2019 China report raises the topic of possible dual-use of civilian research for hard security purposes: "Civilian research could support a strengthened Chinese military presence in the Arctic Ocean, which could include deploying submarines to the region as a deterrent against nuclear attacks. ${ }^{24}$

The increasing Chinese interest in the Arctic has led to the U.S., the EU, and individual Arctic countries raising concerns about China's investments in European critical infrastructure, especially in transport, energy and ICT. ${ }^{25}$ On the political level, the U.S. has employed rather harsh language during the Trump administration, making clear that the Arctic is not an island of peaceful cooperation between the great powers in the race for global power. Secretary of State Mike Pompeo articulated this in May 2019 as follows: "China is already developing shipping lanes in the Arctic Ocean. This is part of a very familiar pattern. Beijing attempts to develop critical infrastructure using Chinese money, Chinese companies, and Chinese 
workers - in some cases, to establish a permanent Chinese security presence. [...] Do we want the Arctic Ocean to transform into a new South China Sea, fraught with militarisation and competing territorial claims?"26

\section{Africa}

China's contemporary engagement in Africa is composed of two distinct phases. The first period ran from 1956 to 1982 and included diplomatic assistance, material support and training for liberation movements, operating under the shadow of the Sino-Soviet split and the drive to exert influence. ${ }^{27}$ Concurrently, Taiwan's previous diplomatic recognition by many African states became another driver for China's efforts to displace Taipei, which is almost completed.

With the onset of Deng Xiaoping's opening policies in the late 1970s, the gradualist shift to a market-oriented approach in China's domestic economy reverberated in its ties with Africa. This was signalled during a tour of the continent by then Premier Zhao Ziyang in 1982, during which he declared that aid programmes would henceforth be made on a "commercial basis" ${ }^{28}$ This fundamentally changed the Chinese approach towards the continent. Moreover, when Beijing launched its consolidation of state-owned enterprises and concomitant "going out policy" in the 1990s, it laid the foundation for the burgeoning economic ties. ${ }^{29}$

As was the case with the Arctic shortly thereafter, the search for energy security took China to Sudan in 1995. The country was host to untapped oil reserves, but also a twenty-year-long civil war and the recent promulgation of Western sanctions against the regime in Khartoum. China National Petroleum Company (CNPC) invested more than a billion USD, the largest foreign investment by China at the time, and tied to a multi-million-dollar concessional loan from China ExIm Bank to build local infrastructure using Chinese construction firms. The pattern for Chinese engagement in Africa stemmed from this initial foray, with subsequent multi-billion so-called resources-for-infrastructure deals in countries such as Angola, Nigeria and Ghana.

Flying the flag of "no domestic political interference" and cultivating the persona of the leading developing state, China was able to capture the attention of African leaders weary of the constraints of neo-liberal strictures on development, and welcoming an opportunity to diversify their economies. Chinese firms and migrants increasingly established themselves across the continent in everything from sophisticated telecommunications and port logistics systems to automobile assembly plants, small farms and rural retail shops. ${ }^{30}$

China is Africa's largest trading partner, with 204 USD billion in two-way trade in 2018, the bulk of which is in the resource sector. ${ }^{31}$ Since 2012, Chinese banks have begun to underwrite loans for regional transport infrastructure projects in East Africa and the Horn of Africa (notionally linked to the BRI after 2017). Long coveted by African governments as key in accelerating development through intra-regional trade, these projects are being built by Chinese construction firms with the use of local sub-contractors and labour, demonstrating the Chinese facility for adjusting 
to African dynamics. At the same time, the fall in commodity prices in 2014 has resulted in a serious debt crisis for many African countries. ${ }^{32}$ The role of China as a leading creditor in Africa, and the way in which it handles this position, is coming to define how African governments understand Chinese claims to a development partnership.

As to geostrategic/geopolitical interests, Beijing's involvement in security affairs runs in three parallel strands. The first, starting in the late 1990s, is its expanding role in multilateral preventive diplomacy and peacekeeping operations..$^{33}$ To date, China has fielded over 30,000 peacekeepers to all African missions mostly in noncombatant roles, but since 2012 also in combat-ready positions in Mali and South Sudan (where it has suffered several losses) to demonstrate its commitment to providing security to the region. China has financed peacebuilding through the UN and the African Union (AU), including the announcement of one billion USD over a ten-year period for the UN peacebuilding fund in 2015, as well as participated in the joint anti-piracy naval task force off the coast of Africa since 2009.

The second strand concerns China's expanding bilateral military relations, most notably its establishment of a military base in Djibouti in the Horn of Africa in 2015 and the possibility of other such installations elsewhere in Africa. Hosting up to 10,000 personnel, Djibouti is China's first and so far only overseas military platform and is linked to Chinese-financed harbour rehabilitation and an industrial export zone, as well as supporting the peacekeeping forces and anti-piracy operations. China has stated that it is purely a "logistics base". At the same time, it also allows China to monitor all shipping movements through the Red Sea and the Gulf of Aden. It has also been seen as a model for future Chinese foreign bases ${ }^{34}$ and a "microcosmos" of China's and U.S. geopolitical rivalry. ${ }^{35}$ In addition, China has several bilateral defence ties with African countries, which vary from country to country, including joint training exercises, arms sales, and even featuring joint military-led commercial ventures in Zimbabwe and Sudan. ${ }^{36}$

Lastly, following the U.S. and Russian practice, there is a growing presence of Chinese private security firms protecting Chinese commercial interests around the continent, supplemented by the secondment of Chinese police to national governments. ${ }^{37}$

China's active role in African affairs has not gone unnoticed, and the continent shows signs of having become a geoeconomic battlefield for great powers. When the U.S. President's (now former) Security Advisor, John Bolton, unveiled the Trump administration's "New Africa Strategy" in December 2018, ${ }^{38}$ many commentators noted that the strategy was actually more about China (and Russia) than Africa. As Bolton put it, China and Russia both are great power competitors of the U.S., who are rapidly expanding their financial and political influence across Africa. "They are deliberately and aggressively targeting their investments in the region to gain a competitive advantage over the United States." In so doing, China in particular "uses bribes, opaque agreements, and the strategic use of debt" to hold states in Africa 


\section{Christer Pursiainen, Chris Alden and Rasmus Bertelsen}

captive to Beijing's wishes and demands. China's quest to obtain more political, economic, and military power in Africa poses "a significant threat to U.S. national security interests".

The EU is much less alarmed than the U.S. While there are some geopolitical issues between the EU and China in Africa as well, it has, however, been noted that in the Horn in particular, Chinese and EU security interests are "largely complementary" as both want to see a stable Horn of Africa devoid of conflict, terrorism or piracy. ${ }^{39}$

\section{Discussion}

From the perspective of the history of rising powers, there is not much new in the generic picture drawn above. In the late nineteenth century, Alfred Thayer Mahan ${ }^{40}$ emphasised, in relation to the then rising great-power U.S., the potential of a strong merchant fleet to increase a state's power to implement its economic imperialism, which in turn needs a strong navy. While the tools and instruments may be different for China in today's more globalised world, the basic code of conduct is this same old geoeconomic/geopolitical maxim.

Another proponent of geopolitics, Halford Mackinder, in turn coined the term "geographical pivot", ${ }^{41}$ an area which as such is not a power centre but whose location and situation in certain conditions has become essential for the great powers in their bigger game. Both the Arctic and Africa (especially the Horn) fit this definition in the current era.

In its march towards securing control of these pivot areas, China is just at the beginning. Its own efforts are not sufficient to achieve its ambitions, so it needs recourse to alliances. Indeed, its preferred approach seems to be to ally with established states as regional interlocutors to promote its increasingly shared interests while limiting direct exposure as well as providing an opportunity to learn about local complexities. China has had some success in allying with Russia in the Arctic. In African countries, as South African power unexpectedly diminished over the last decade, China has had to rely on several weaker authoritarian leaders instead.

The way in which China will reconcile the need to secure its geoeconomic interests in the Arctic and Africa with non-interference policies remains a challenge. A further challenge concerns how the rise of the "new geopolitics", led by a newly assertive U.S. policy towards China as a strategic competitor and given expression in the "debt diplomacy" debate out of Washington, will impact China-Africa ties.

\section{Regimes and governance}

China's strategies towards the Arctic and Africa alike are based on and often legitimated not only through bilateral agreements, but also global and regional regimes and governance systems. In short, international regimes are "principles, norms, rules, and decision-making procedures around which actors' expectations converge" in the absence of centralised public authority. ${ }^{42}$ For realists, regimes are a reflection 
of the great power relations related to the region or issue area, usually in terms of formal institutions. For institutionalists, regimes have, or may have, their own causal power, especially in overcoming cooperation problems through repeated reciprocal positive tit-for-tat experiences that they facilitate. Constructivists are more interested in informal cultures, norms and behavioural rules that grow from interaction and may enable a certain practice of interstate cooperation or conflict. Governance, in turn, a concept stemming from European studies some thirty years ago, emphasises the horizontal dimension of the issue. In the international context, governance is not only about state-level cooperation, but also complicated multi-level structures, including civil societies, private actors and scientific institutions, among others, in complex and mixed settings. ${ }^{43}$

From the above perspectives, several new research questions arise. How and through which mechanisms has China as a great power adapted to the existing governance systems in the Arctic and Africa? What about the domestic legislation of the regional states? Is China's policy only adaptive, or does it try to influence the existing international regimes and domestic arrangements? Has China made efforts to create new regimes or governance systems, more favourable to its perceived interests, in the two respective geographical areas?

\section{The Arctic}

The study of regimes has often been preoccupied with their formation. In the Arctic, this period occurred after the Cold War in the 1990s. The Arctic regime formation, such as the Arctic Council (AC), did not follow the scheme of a hegemonic actor imposing its order, but was instead a multivariate and dynamic process comprising several stages, such as initial agenda-setting, negotiation period, and operationalising - and depending on the right timing. ${ }^{44}$ The development that started with the AC was followed by many more "Arctic governance" approaches, where not only states were active but the indigenous minorities, private actors, civil societies and the research community as well. ${ }^{45}$

China is rather outspoken in its Arctic White Paper ${ }^{46}$ in that it sees itself as an actor having a right, and even an obligation, to participate in Arctic governance and its further formulation, but not claiming any Arctic sovereignty. Its description of this governance system focuses on global rather than regional regimes, however. The strongest emphasis is therefore on those regimes where China is a full member with a great-power status, namely the Charter of the UN, the 1982 UN Convention on the Law of the Sea (UNCLOS), as well as other lower-lever global treaties and institutions (e.g. IMO).

This enables China - quite correctly - to point out that while states from outside the Arctic region do not have territorial sovereignty in the Arctic, "they do have rights in respect of scientific research, navigation, overflight, fishing, laying of submarine cables and pipelines in the high seas and other relevant sea areas in the Arctic Ocean, and rights to resource exploration and exploitation in the Area". Following 


\section{Christer Pursiainen, Chris Alden and Rasmus Bertelsen}

the Spitsbergen Treaty from 1920, which the Republic of China joined in 1925, and which China 'rediscovered' in the late $1990 \mathrm{~s},{ }^{47}$ China also enjoys "the liberty of access and entry to certain areas of the Arctic, the right under conditions of equality and, in accordance with law, to the exercise and practice of scientific research, production and commercial activities such as hunting, fishing, and mining in these areas". China thus claims that it plays 'a constructive role' in the formulation of Arctic-related international rules. While it participates in Arctic affairs on the basis of existing rules and mechanisms, it will also contribute to "the making, interpretation, application and development of international rules regarding the Arctic". ${ }^{48}$ In so doing, China says it participates in safeguarding "the common interests of all nations and the international community". This in turn is said to be based on Chinese general foreign policy principles of "respect, cooperation, win-win result and sustainability".

The AC is also mentioned in positive terms in the Arctic White Paper, albeit only in one paragraph. China's urge to become more involved in Arctic governance actually started in 2007, when it became an ad hoc observer in the AC. Allegedly, its further efforts to become a permanent observer were first met by suspicion, especially on the part of Canada, Russia and the U.S. This in turn led China to enhance its bilateral diplomacy with the Arctic States (the eight Member States of the AC), which proved to be very successful. Canada and Russia remained most sceptical, but the U.S. mediated, and China was approved in 2013 as part of a package of five new Observer states. ${ }^{49}$

In the context of enlarging the number of observers, new observer criteria were elaborated, including the promise to comply with the $\mathrm{AC}$ procedures and principles, contributing to the work of the AC, and reasserting the interest in being an observer every four years. ${ }^{50}$ While China's observer role in the AC has later created some concern, it has been however reminded that the observer role does not provide access to the council's decision-making and the $\mathrm{AC}$ as such does not make important decisions but its Member States. At the same time, it provides China to be legitimately included in the generic debates about the Arctic. ${ }^{51}$

The case of the multilateral Agreement to Prevent Unregulated High Seas Fisheries in the Central Arctic Ocean illustrates China's long-term Arctic strategy. Applying the precautionary principle, the coastal states of the Arctic Council Canada, Greenland/Denmark, Norway, Russia, and the United States signed a declaration in 2015 to the effect that commercial fishing should not start in the 2.8-million-squarekilometer high seas area until adequate scientific research for sustainable fishing and management rules are in place. These states then called on major non-Arctic fishing countries to join negotiations for a binding agreement. In October 2018, the above five states, together with Iceland, China, Japan, South Korea and the European Union signed the agreement. Why did China agree? It has been argued that for China the Arctic fisheries is more than a fishing issue. By joining the agreement, China opened a new path to be involved in Arctic governance and at the same time reduced concerns among Arctic states about China's intentions. ${ }^{52}$ The role of the 
agreement has been seen as piloting an emerging new Arctic governance model ${ }^{53}$ with China as a full member. At the same, it has been noted that no Chinese or any other states' vested interests were yet in play as there are currently no commercial fisheries in the area. ${ }^{54}$ In that sense, there were no immediate costs but several diplomatic and science-diplomacy benefits for China.

The Arctic White Paper ${ }^{55}$ includes some remarks on China's bilateral relations, touching upon the issue of how it adapts to the domestic regimes in the region. It explains how the activities of Chinese citizens, legal persons or other organizations in the Arctic are supervised in accordance with the law to ensure that their activities accord not only with international law, but that they also respect the relevant national laws on environmental protection, resource conservation, and sustainable development. China furthermore carries out bilateral consultations on Arctic affairs with all Arctic States.

Indeed, "Beijing has been improving bilateral communication with individual states along the Arctic Circle" and "bilateralism has been an essential part of China's Arctic engagement" ${ }^{56}$ In infrastructure investments, however, this has most often taken place in a business-to-business fashion, where, in the initial phase, the direct state level has been largely absent.

China's way of presenting Arctic governance is logical, moving from global to regional regimes and then domestic systems. ${ }^{57}$ However, the message is clear: China has equal rights in the high sea areas, including the seabed. Moreover, China aspires to become a norm-maker instead of remaining only a norm-taker in the region. ${ }^{58}$ While China has emphasised a win-win approach, the research community seems to be divided between alarmist, more moderate, and mainly positive analyses ${ }^{59}$ regarding China's real motives in the Arctic.

Of the state actors, the U.S. is now the most critical with Secretary of State Pompeo's May 2019 Rovaniemi speech. He noted, aiming at China in particular, that all of the parties in the "Arctic marketplace" have to play by the same rules. "Those who violate those rules should lose their rights to participate in that marketplace". He claimed that Chinese investments may undermine domestic rule- and law-based societies and high level of infrastructure quality in the Arctic. ${ }^{60}$ The EU bodies are again more cautious, pointing out that "China will be measured against its actions rather than its rhetoric". ${ }^{11}$ The Commission outlined its balancing line in the following way: "China is, simultaneously, in different policy areas, a cooperation partner with whom the EU has closely aligned objectives, a negotiating partner with whom the EU needs to find a balance of interests, an economic competitor in the pursuit of technological leadership, and a systemic rival promoting alternative models of governance". ${ }^{62}$

\section{Africa}

Africa's abundant resources, weak state structures and strategic position are the defining features that situate the continent in relation to the international system. ${ }^{63}$ 


\section{Christer Pursiainen, Chris Alden and Rasmus Bertelsen}

External powers have sought out African resources in a context where local states have only limited capacity to effectively regulate their role. Recognition by African elites of the continent's strategic position in relation to either specific resources or geographical location has produced an approach which cannily employs external powers as a resource in their own domestic power struggles. ${ }^{64}$

As a result, the African continent historically served as a site of contestation between external powers, sometimes deliberately fostered by local elites. Although the majority of states are democracies today, they lack the requisite financial and human capital to perform rudimentary functions of governance. Therefore - whether democratic or authoritarian - African governments have presided over some of the most egregious violations of labour, human and environmental rights and, paradoxically and over time, some of the most progressive formal and informal regulatory regimes. In this unstable context, corruption has thrived and China's celebration of its non-conditional aid and lack of transparency in its economic dealings with African governments together with China's status as alternative to Western powers effectively supports the spread of these practices.

Efforts to promote democratic norms in Africa, such as elections, transparency and effective resource governance through the Extractive Industries Transparency Initiative (EITI) and the Kimberley Process have been moderately successful. On the other hand, Chinese support for Western designated 'pariah regimes' in Africa has proved to be an important diplomatic prop. Evidence suggests that African voting patterns on issues in the Human Rights Council and in the UN General Assembly cohere more closely with Beijing's positions in line with growing economic dependency ${ }^{65}$ African trade unions, NGOs and civil society actors have been at the forefront of demanding accountability from Chinese firms and their own governments. The emphasis on Corporate Social Responsibility initiatives by Western and - at least nominally - by Chinese firms operating in the resource sector is an explicit acknowledgement that African regulatory regimes are not functioning well.

China has adopted a positive attitude towards African regional organisations, installing its appointed representatives in the most important ones, while in the global arena emphasising African nations' self-reliance in resolving their problems. China has generally aimed for aligning its policies with those of the African Union (AU) and other relevant regional organizations, rather than pushing demands onto them, thus utilising "convergences between its own views and those of key African regional bodies". ${ }^{66}$

Numerous declarative regimes on issues as varied as continental maritime governance and industrial policy have been launched by the AU, with limited to no effective adherence. In terms of external power relations, the continuous dependency of Francophone states on the CFA franc has allowed Paris to exercise considerable influence over their economies. ${ }^{67}$ In a similar way (and reminiscent of USD 
ascendancy), China's stated goal of the internationalisation of the renminbi, accelerated after it was acknowledged by the IMF as a basket of currencies with special drawing rights, prompted several African countries to create renminbi currency conversion centres. ${ }^{68}$ The repayment of Chinese loans through recourse to the renminbi is one of the proposed responses to the new African debt crisis.

The challenge of national regulatory regimes, for instance in the DR Congo, lies in the density of legislation and the concurrent capacity or desire of African governments to enforce rules instead, in the absence of the regimes themselves. Constitutional democracies like Ghana and Botswana have invested in their institutions and have tended to exhibit stronger commitments to the rule of law. ${ }^{69}$ Notably, both of these countries have at one time or another rejected Chinese involvement in specific sectors: in the case of Ghana, the parliament initially rejected a proposed oil for infrastructure deal, while in the case of Botswana, the president cancelled infrastructure projects outright when the Chinese failed to meet expected standards and commitments. Even Chad, an authoritarian regime with considerable Chinese investments in developing a domestic oil refinery, has defied the logic of dependency and issued a 1.2 USD billion fine to the CNPC for violations of its contract in 2014.

At the same time, there is considerable evidence that despite African governments' formal adherence to declaratory regimes of conduct, there are only sporadic efforts to enforce them. The logic of elite conduct has claimed to be a function of "the political instrumentality of disorder"; that is to say that African leaders actively subverted constitutional restrictions and regulatory commitments, which served to constrain their arbitrary exercise of power. ${ }^{70}$ This may explain the pointed use of regulatory power by, for instance, the Chadian government against Chinese economic interests.

Apart from the invariably critical attitude of the U.S. towards China's business model in Africa, the $\mathrm{EU}^{71}$ notes that while China's investment activity in Africa has contributed to the growth of many receiving economies, at the same time "these investments frequently neglect socioeconomic and financial sustainability and may result in high-level indebtedness and transfer of control over strategic assets and resources". In so doing, China compromises good social and economic governance and, most fundamentally, the rule of law and human rights in Africa.

\section{Discussion}

The situation covered above is characterised by the fact that China is a latecomer and, indeed, an outsider in the regional regimes of both the Arctic and Africa. In the Arctic, it has nonetheless made efforts to position itself to influence future rulemaking, and to compensate for its regional outsider role by putting emphasis on more general global regimes where it is a full member. In the case of Africa, it has 


\section{Christer Pursiainen, Chris Alden and Rasmus Bertelsen}

tried to utilise the weak international or regional governance environment in general, to align its interests with the African governance system.

Yet many of China's operations are conditioned by regional states' domestic regulations, such as environmental legislation, working rights, and local autonomy. While strong domestic regulations in the Arctic considerably limit China's actions, in Africa, conversely, weak governance structures give China much greater room for manoeuvre. The question is in which direction the massive Chinese business and investment penetration into the Arctic and African countries is heading; will it adapt to the existing practices in these countries, or will it lead to some kind of evolutionary conversion of the social-economic systems with increased Chinese characteristics, especially in Africa?

The degree to which Chinese firms are able to adopt new approaches and improved practices in their operations in both the Arctic and Africa, demonstrating greater compliance with local regulatory regimes, remains a challenge.

\section{Identities and roles}

In the study of international politics, at least three main approaches can generally be discerned regarding how and why identities are constructed. The first approach sees identity formation as taking place in interactive socialisation processes in the international system between states ${ }^{72}$ whereas the second puts more emphasis on endogenous historical processes and internal discourses within states. ${ }^{73}$ The third claims that identity is chosen based on how well it is accepted by other states and how well it coincides with the nation's own perception of its past and history. ${ }^{74}$ The latter is the most interesting from our point of view.

Scholars on identity typically argue that identity is a more fundamental characteristic of a state than interest because the latter is based on the former. ${ }^{75}$ Identity indicates which larger group the state or nation identifies with and from which it wants to differentiate itself, and how strongly. States - and their representative politicians and officials - follow a particular foreign policy in line with what their identity indicates. It is through these choices that states also communicate with each other about the way in which they want to be treated.

The step from identity to role is not big. Some role theorists talk about identity and role in an almost reciprocal way; if a role is genuinely adopted, it becomes an identity. A point related to our topic is the argument that states may not have just one role, but may adopt or act according to different roles depending on the situation and specific conditions. This involves the possibility that roles are unfair reflections of true identity. They may be used to conceal a genuine identity or to benefit from the expectations and practices of that role. ${ }^{76}$

The above focus leads us to formulate some primary research questions for the current section. What are China's identity and roles vis-à-vis the Arctic and Africa respectively? Does it have regionally adapted identities or roles to these regions? If so, can they be regarded as genuine identities, perhaps constituting China's interests 
in the regions, or are they rather roles played in order to justify goals related to mere power political or material interests? And, crucially, how intersubjective - respected by other states - are these identities and roles?

\section{The Arctic}

In the Arctic, China describes itself with attributes such as "responsible major country", "near-Arctic state", "Arctic stakeholder", and "polar great power". While this practice can be traced back to the early $2010 \mathrm{~s},{ }^{77}$ it is most notably expressed in the country's 2018 Arctic White Paper. ${ }^{78}$

One could argue with good reason that the self-proclaimed identity of a "nearArctic state" is more about instrumental interest-based role seeking, rather than a genuine identity. This role is aimed at decreasing the gap between China and the Arctic States proper, especially in perceiving the high seas and international seabed (outside national exclusive economic zones) of the Arctic as a common good, open to resource extraction. Some Chinese analysts claim that "the dichotomy between Arctic and non-Arctic states in general violates UNCLOS because it automatically puts non-Arctic states in an inferior position". ${ }^{79}$ Others have remarked that the "near-Arctic state" has the benefit of differentiating China from the other nonArctic states that are geographically located even further away. The term "nearArctic state" has also been used in connection with the effects of Arctic climate change on Chinese weather and environment. ${ }^{80}$

China's "near-Arctic" role is not shared in official Western comments. China is explicitly seen by the U.S. as a revisionist actor in the area, which seeks to challenge the status quo through the use of identity politics: "Beijing claims to be a 'NearArctic State', yet the shortest distance between China and the Arctic is 900 miles. There are only Arctic States and Non-Arctic States. No third category exists [...]." ${ }^{\prime 1}$ The U.S. reluctance to give China any say in Arctic governance was also confirmed in the Joint Statement between the U.S. and Finnish Presidents in October 2019: "Arctic governance, guided by applicable international law, is the responsibility of Arctic nations, particularly through the Arctic Council." 82

The Arctic States are collectively more diplomatic. In the 2019 AC Foreign Ministerial meeting's Joint Declaration, they emphasised the "leadership" of the Arctic States, but also "recognized the positive contributions of Observers to the work of the Arctic Council, its Working Groups and other subsidiary bodies". ${ }^{83}$

\section{Africa}

The focus on China's interests in African resources, and to a lesser degree African markets, belies the broader role that identity plays in framing the relationship, and is likewise indicative of Beijing's aspirations for its future trajectory. China and Africa are regularly declared to share common features, including the historical scourge of colonialism and underlying development challenges that are its legacy. ${ }^{84}$ China 


\section{Christer Pursiainen, Chris Alden and Rasmus Bertelsen}

claims to be the "world's largest developing country", and Africa has the most developing countries in the world. This of course is a syllogism which is meant to denote a collective identity and development imperative, but which manages to highlight the fundamental asymmetries in the relationship. ${ }^{85}$

In a way, China placing itself first among developing countries resembles the U.S.'s traditional understanding of itself as the "leader of the free world", or the Soviet understanding of itself as the "leader of the progressive forces"; that is, China is effectively mirroring the former super powers' identity politics in its search for a new global role.

The modality of economic involvement between China and Africa is founded on "South-South Cooperation", a term that encompasses all manner of activities from in-kind technical exchanges to conventional business deals underwritten by policy banks at commercial rates. In more recent years, this language has been recast to fit the broad narratives of a "common destiny" between China and the world emerging out of the BRI. Underpinning this is a widening network of educational and cultural programmes, including scholarships and training programmes for 60,000 African students, and 54 Confucius Centres based in African universities, as well as the expansion of Chinese language training at 27 secondary schools in parts of Africa. ${ }^{86}$ The Forum on China-Africa Cooperation (FOCAC), established in 2000 as a tri-annual diplomatic gathering of leaders, sets targets for its future development and serves as a site for collective norm articulation and convergence. ${ }^{87}$ Thus, China, in its "going global policy" in relation to Africa, has increasingly used soft power elements in its identity politics, following the practices of other great powers.

China's identity approach towards Africa has been directly contested by the West, not only by the U.S. but now also by the EU. According to the latter, "China can no longer be regarded as a developing country. It is a key global actor and leading technological power". ${ }^{8}$

\section{Discussion}

There is not much difference between China's economic/power-political aspirations and its Arctic or Africa-related adopted (state) identities. Unlike what constructivism would claim, at the onset at least, the causality seems to work from the latter towards regional identity formation, rather than vice versa. China's rising great-power aspirations lead it to consider not only its global role, but at the regional level it also actively utilises identity vocabulary to enhance and justify its strategic economic and power interests. So, it is actually not a question of regional identity at all, but rather of cleverly designed role-plays, taking into account the variety of regional contexts. Only when brought into a bigger perspective, can one see the common adaptive logic of these policies.

When it comes to the Arctic, China's self-proclaimed "near-Arctic state" identity seems to be an opportunistic self-constructed role to enhance its economic and 
power-political interests, rather than any genuine identity, a stance which has been rejected by other actors. In Africa, China has recently softened its "leader of developing countries" approach based on economics and trade alone. China has become highly aware of the fact that certain Chinese policies are producing negative perceptions among Africans, and has added more non-economic and nuanced soft power elements to its engagement strategy with Africa, ${ }^{89}$ as briefly presented above. The same goes for the Arctic, where Chinese soft power is often exercised, for instance, in terms of so-called science diplomacy, with the goal of becoming a more accepted actor in Arctic affairs. ${ }^{90}$

The notion of identity policy however leads us to consider whether China's carefully chosen tactical identities or roles vis-à-vis the Arctic and Africa respectively will, as time passes, nonetheless lead to more established and genuine regional identities for the country, and what that would entail, for instance, in terms of its abovementioned "core interests". Would these developing new regional identities affect the interpretation of the non-negotiable red lines of China's interests?

\section{Conclusions}

We have considered China's policies towards the Arctic and Africa respectively, from three overlapping perspectives: geoeconomics and geopolitics; regimes and governance; identities and roles. Our conclusions are summarised in Table 1.

First, by discussing the so-called core interests of China and their foreign policy implications, we argue that China's regional geoeconomic policies are driven by its urge for further domestic and relative economic growth and through that, more fundamentally, domestic stability. This motivation implies commonality between China's cross-regional policies under the more generic foreign policy goals and geoeconomic interests. These interests in turn sometimes require power-political backing in terms of a private or public form of Chinese security presence. Slowly, Chinese military policy is also being upgraded in order for the country to become a global actor capable of defending its national security interests in the regional geopolitical settings discussed here.

Second, we contend that China utilises its membership in more generic international regimes, such as UN-based institutions and international law in general, in order to maximise its freedom of action. China as a rising great power also tries to penetrate and participate in developing international regional regimes while at the same time drawing on bilateral agreements with regional governments. Regional allies provide a host of important functions for China, from access to resources and infrastructure opportunities for Chinese firms, to local knowledge and legitimacy, which are important in shaping and improving Chinese strategy and policy responses towards these regions.

Third, considering China's identities and roles, as a kind of external newcomer to the regions discussed here, we conclude that it is mostly a question of carefully 
Table 1. Determinants defining China's growing role and position in the Arctic and Africa

\begin{tabular}{|c|c|c|}
\hline $\begin{array}{l}\text { China's regional } \\
\text { determinants }\end{array}$ & The Arctic & Africa \\
\hline Geoeconomic interests & $\begin{array}{l}\text { - Mining minerals } \\
\text { - Transport infrastructure } \\
\text { - 'Polar silk road' (Northeast Passage) } \\
\text { - Compensating for the lack of } \\
\text { sovereign Arctic territory with } \\
\text { ability to finance large-scale Arctic } \\
\text { development projects }\end{array}$ & $\begin{array}{l}\text { - Mining minerals } \\
\text { - Transport infrastructure } \\
\text { - BRI } \\
\text { - Financing large-scale development } \\
\text { projects }\end{array}$ \\
\hline $\begin{array}{l}\text { Geostrategic/geopolitical } \\
\text { interests }\end{array}$ & $\begin{array}{l}\text { - Relevance to China's national } \\
\text { security not openly outlined } \\
\text { - US speculations about China } \\
\text { deploying submarines to the region } \\
\text { in the future as a deterrent against } \\
\text { nuclear attacks } \\
\text { - No military structure but } \\
\text { possibly dual-use technology and } \\
\text { infrastructure, including its satellite } \\
\text { system }\end{array}$ & $\begin{array}{l}\text { - Relevance acknowledged since } 2012 \\
\text { through FOCAC partnership/UN } \\
\text { multilateral PKO } \\
\text { - 1st overseas military base at Djibouti } \\
\text { - Critical infrastructure financing } \\
\text { (harbours), industrial park }\end{array}$ \\
\hline $\begin{array}{l}\text { International regimes } \\
\text { and governance }\end{array}$ & $\begin{array}{l}\text { - Focusing on UN regulations to use } \\
\text { the sea, especially UNCLOS and } \\
\text { IMO Polar Code } \\
\text { - Observer in the Arctic Council, but } \\
\text { while opening channels also obliging } \\
\text { to comply with its principles } \\
\text { and seven criteria for observers, } \\
\text { including the recognition of Arctic } \\
\text { states' sovereignty, sovereign rights } \\
\text { and jurisdiction in the Arctic } \\
\text { - China's aspiration to transform the } \\
\text { Arctic governance from regional } \\
\text { to more global for the benefit of } \\
\text { humankind }\end{array}$ & $\begin{array}{l}\text { - Rhetorical adherence to } \\
\text { international and regional regimes } \\
\text { - FOCAC, a regional diplomatic } \\
\text { forum to reframe norms in line with } \\
\text { Chinese and Africa preferences (no } \\
\text { Western govts allowed in) } \\
\text { - Aid regimes and practices crucial } \\
\text { entry point for China - breaking } \\
\text { OECD 'donor cartel' through no } \\
\text { conditionalities approach } \\
\text { - Agrees to observer status at OECD- } \\
\text { DAC }\end{array}$ \\
\hline $\begin{array}{l}\text { Domestic regimes } \\
\text { (of the region) }\end{array}$ & $\begin{array}{l}\text { - The Arctic States, except Russia, } \\
\text { are recognised rule of law-based } \\
\text { countries, including strong working } \\
\text { rights and environmental regulation, } \\
\text { limiting China's freedom of action }\end{array}$ & $\begin{array}{l}\text { - Bilateral approaches to workers' } \\
\text { rights or environment vary } \\
\text { depending on African governments' } \\
\text { requirements } \\
\text { - China's 'demand driven'/ } \\
\text { no conditionalities approach } \\
\text { encourages reduced compliance with } \\
\text { international norms } \\
\text { - Appealing to 'pariah' regimes }\end{array}$ \\
\hline $\begin{array}{l}\text { Sub-global identities } \\
\text { of China }\end{array}$ & $\begin{array}{l}\text { - China's urge to be a 'responsible } \\
\text { major country', 'polar great power', } \\
\text { 'near-Arctic state' and an 'Arctic } \\
\text { stakeholder', seeing the high seas } \\
\text { and international seabed of the } \\
\text { Arctic as a common good, open to } \\
\text { resource extraction }\end{array}$ & $\begin{array}{l}\text { - 'Leading developing country' that } \\
\text { can serve as a model of development } \\
\text { for Africa } \\
\text { - China and Africa have a 'common } \\
\text { destiny', shared history of } \\
\text { colonialism, etc. } \\
\text { - BRI identity only East/Horn of } \\
\text { Africa maritime route meaningful }\end{array}$ \\
\hline
\end{tabular}


fabricated sub-global or regional role-play, rather than a question of genuine identities at this point. While identities are not driving interests in China's sub-global policies - quite the converse in fact - these current tactical identities or roles might still become more closely connected to China's real great-power identity, and through that its national core interests, as time goes on.

Fourth, our overall conclusion is that China's sub-global strategies clearly reflect and make sense only in the context of the general Chinese grand strategy of a country that is slowly but surely aiming at taking on the role of the leading global superpower. Yet the Chinese foreign policy system is characterised by rather flexible and adaptive strategies, managing to tailor its so-called core interests and foreign policy principles to sub-global conditions. As its core interests lie in preserving the current political system and power relations within China, it is not, unlike the Soviet Union, interested in exporting its own economic and political system more widely, although Xi Jinping has become less shy about promoting the Chinese model.

Finally, some Chinese system characteristics will inevitably affect the regions and countries where it enhances its economic and military position, with its formal and informal values, norms, rules and practices. The experience shows that China can utilise its power in relation to weaker countries and regions. The lessons for such hugely different regions as the Arctic and Africa in this context are, however, the same. Strong regional and domestic institutions, based on rule of law and sustainable development goals function as barriers against the penetration of negative effects of the Chinese presence. A threat to the functioning of these barriers is if China manages to create bilateral relations based on one-sided dependence, using its economic power and utilising other parties' vulnerable situations, such as economic crises. At the same time, it is possible that China's increasing presence, especially in strong democracies and market economies, may gradually and in the long term also modify Chinese practices in the spirit of a convergence of systems through interaction and globalisation.

\section{NOTES}

1. See: R. D. Kaplan, “America must prepare for the coming Chinese empire," The National Interest (June 17, 2019), http://www.nationalinterest.org/feature/america-must-preparecoming-chinese-empire-63102 (accessed 3 March 2020); S. Zhao, "The China Model: can it replace the Western model of modernization?", fournal of Contemporary China 19(65), (2010), 419-436; S. Halper, The Beijing Consensus. How China's Authoritarian Model Will Dominate the Twenty-first Century (New York: Basic Books, 2010); I. Bremmer, The End of the Free Market. Who Wins the War Between States and Corporations? (New York: The Penguin Press, 2010); C. F. Bergsten, C. Freeman, N. R. Lardy and D. J. Mitchell, China's Rise. Challenges and Opportunities (Washington D.C.: Center for Strategic and international Studies, 2009); M. Jacques, When China Rules the World. The End of the Western World and the Birth of a New Global Order (New York: The Penguin Press, 2009); J. J. Mearsheimer, "China's Unpeaceful Rise," Current History 105, No. 690, (2006), 160-162. 


\section{Christer Pursiainen, Chris Alden and Rasmus Bertelsen}

2. S. Tang, "China and the Future International Order(s)," Ethics E International Affairs Vol. 32, Special Issue 1, (2018), 31-43; M. J. Mazarr, T. R. Heath, and A. Stuth Cevallos. China and the International Order (Santa Monica, Calif.: RAND Corporation, 2018); M. Mucchie and L. Xing, "The Myths and Realities of the Rising Powers. Is China a Threat to the Existing World Order?," in The Rise of China and the Capitalist World Order, ed. L. Xing (New York: Routledge, 2018), 51-70; D. C. Kang and M. Xinru, "Power Transitions: Thucydides Didn't Live in East Asia," The Washington Quarterly 41:1 (2018), 137-154; E. S. Steinfeld, Playing Our Game. Why China's Rise Doesn't Threaten the West (Oxford: Oxford University Press, 2010).

3. S. W. Khan, Haunted by Chaos: China's Grand Strategy from Mao Zedong to Xi Finping (Harvard: Harvard University Press, 2018); Y. Wang, "Offensive for defensive: the belt and road initiative and China's new grand strategy," The Pacific Review Vol. 29, Issue 3 (2016), 455-463; Y. Zheng and L. F. Lye, "China's Foreign Policy: The Unveiling of President Xi Jinping's Grand Strategy," East Asian Policy Vol. 07, No. 1 (2015), 62-82; T. Fallon, "The New Silk Road: Xi Jinping's Grand Strategy for Eurasia. American Foreign Policy Interests," The fournal of the National Committee on American Foreign Policy Vol. 37, Issue 3 (2015), 140-147; W. Jisi “China's Search for a Grand Strategy: A Rising Great Power Finds Its Way," Foreign Affairs Vol. 90, No. 2 (2011), 68-79.

4. R. Si and P. Katzenstein, "Analytic Eclecticism in the Study of World Politics: Reconfiguring Problems and Mechanisms across Research Traditions," Perspectives On Politics Vol. 8(2) (2010), 411-431.

5. F. Leverett and Wu Bingbing, "The New Silk Road and China's Evolving Grand Strategy," The China fournal No. 77, 110-132.

6. S. Strange, States and Markets (London: Bloomsbury, 2015); D. Stokes and K. Waterman, "Security Leverage, Structural Power and US Strategy in East Asia," International Affairs 93:5 (2017), 1039-1060.

7. N. Kitchen and M. Cox, "Power, Structural Power and American Decline," Cambridge Review of International Affairs (2019), https://doi.org/10.1080/09557571.2019.1606158 (accessed 3 March 2020).

8. D. Stokes and K. Waterman, "Security Leverage, Structural Power and US Strategy in East Asia."

9. S. Scholvin and M. Wigell, "Power politics by economic means: Geoeconomics as an analytical approach and foreign policy practice," Economic and Political Studies Vol. 6, Issue 3 (2018), pp. 73-84; A. Vihma, "Geoeconomics Defined and Redefined," Geopolitics, Vol. 23, Issue 1 (2018), 47-49; M. Mattlin and M. Wigell, "Geoeconomics in the Context of Restive Regional Powers," Asia Europe fournal Vol. 14, Issue 2 (2016), 125-134; D. Cowen and N. Smith, "After Geopolitics? From the Geopolitical Social to Geoeconomics," Antipode. The Radical fournal of Geography Vol. 41, Issue 1, (2009), 22-48; E. N. Luttwak, "From Geopolitics to Geo-Economics: Logic of Conflict, Grammar of Commerce," The National Interest, No. 20, Summer (1990), 17-23.

10. See: A. F. Mahan, The Influence of Sea Power Upon History. 1660-1783 (London: Methuen, 1965/1890); H. J. Mackinder, "The Geographical Pivot of History," The Geographical fournal Vol. 23, No. 4 (1904), 421-437; N. J. Spykman, The Geography of the Peace (New York: Harcourt, Brace and Company, 1944); Z. Brzezinski, The Grand Chessboard: American Primacy and Its Geostrategic Imperatives (New York: Basic Books, 1997).

11. M. Beeson, "Geoeconomics with Chinese Characteristics: the BRI and China's evolving grand strategy," Economic and Political Studies Vol. 6, Issue 3 (2018), 240-256; Y. Wang, "Offensive for defensive: the belt and road initiative and China's new grand strategy"; T. Fallon, “The New Silk Road: Xi Jinping's Grand Strategy for Eurasia. American Foreign Policy Interests"; J. C. Hsiung, "The Age of Geoeconomics, China's Global Role, and 
Prospects of Cross-Strait Integration," Fournal of Chinese Political Science Vol. 14, Issue 2 (2009), 113-133.

12. PRC State Council, China's Arctic Policy (White Paper) (The State Council Information Office of the People's Republic of China. January, First Edition, 2018) http://www.scio.gov. $\mathrm{cn} / \mathrm{m} / 32618 /$ Document/1618217/1618217.htm (accessed 3 Jan. 2020).

13. State Council of China, China's Peaceful Development, (Information Office of the State Council, The People's Republic of China, Beijing, September 2011), http://www.gov.cn/english/ official/2011-09/06/content_1941354.htm (accessed 3 Jan. 2020).

14. J. Zhou, "China's Core Interests and Dilemma in Foreign Policy Practice," Pacific Focus, Inha fournal of International Studies Vol. 34, Issue 1 (2019), 31-54; J. Zeng, Y. Xiao and S. Breslin, "Securing China's Core Interests: The state of the debate in China," International Affairs 91(2) (2015), 245-266; Z. Feng, What Are China's Core Interests? (China-US focus, 2014) https://www.chinausfocus.com/foreign-policy/what-are-chinas-core-interests-2 (accessed 15 Apr. 2020); M. D. Swaine, "China's Assertive Behavior. Part One: On 'Core Interests'," China Leadership Monitor, no. 34 (2011), https://carnegieendowment.org/files/ CLM34MS_FINAL.pdf (accessed 3 Jan. 2020).

15. PRC State Council, China's Arctic Policy (White Paper).

16. A. Stepien, L. Kauppila, S. Kopra, J. Käpylä, M. Lanteigne, H. Mikkola and M. Nojonen, "China's Economic Presence in the Arctic: Realities, Expectations and Concerns," in T. Koivurova and S. Kopra (eds.), Chinese Policy and Presence in the Arctic (Nijhoff: Brill, 2020), $90-136$.

17. S. Sengupta and S. Lee Myers, "Latest Arena for China's Global Ambitions: The Arctic", The New York Times, May 24, 2019.

18. J. W. Zeuthen and M. Raftopoulos, "Promises of Hope or Threats of Domination: Chinese mining in Greenland," The Extractive Industries and Society 5(1) (2018), 122-130; A. Higgins, "Teeing off at the Edge of the Arctic? A Chinese Plan Baffles Iceland," The New York Times (22 March 2013); A. Higgins, "A Rare Arctic Land Sale Stokes Worry in Norway," The New York Times (27 Sep. 2014); M. Breum and J. Chemnitz, "No, Greenland does not belong to China," The New York Times (20 Feb. 2013).

19. A. Ryzhova. "On the prospects for China's cooperation with the Arctic countries," IOP Conference Series: Earth and Environmental Science 2020, https:/iopscience.iop.org/article/10.1088/1755-1315/539/1/012045/pdf (accessed 30 August 2020), 5.

20. C. H. and T. Røseth, "The Arctic Dimension in Sino-Russian Relations," In Sino-Russian Relations in the 21st Century, eds. Jo Bekkevold and Bobo Lo (London: Palgrave Macmillan, 2018), 167-187, here 167.

21. F. Lasserre and O. Alexeeva. "An analysis on Sino-Russian cooperation in the Arctic in the BRI era," Adv Polar Sci (2018), 29(4): 269-282; E. Downs, J. Henderson, M. E. Herberg, S. Itoh, M. L. O'Sullivan, M. Skalamera, M., et al., The Emerging Russia-Asia Energy Nexus. NBR Special Report no. 74 (The National Bureau of Asian Research, 2018).

22. J. Weber. "Limited Cooperation or Upcoming Alliance? Russia, China and the Arctic", in Handbook on Geopolitics and Security in the Arctic. Frontiers in International Relations, ed. J. Weber (Switzerland: Springer, 2020), 345-361.

23. X. Li and R. G. Bertelsen, "The Drivers of Chinese Arctic Interests: Political stability and energy and transportation security," in Arctic Yearbook 2013, eds. L. Heininen, H. ExnerPirot and J. Plouffe (2013), 1-16, http://www.arcticyearbook.com (accessed 1 April 2020).

24. Office of the Secretary of Defence, Annual Report to Congress. Military and Security Developments Involving the People's Republic of China 2019 (US: Office of the Secretary of Defense, 2019), 114, https://media.defense.gov/2019/May/02/2002127082/-1/-1/1/2019_CHINA_ MILITARY_POWER_REPORT.pdf (accessed 18 Feb. 2020); cf. M. R. Pompeo, Speech: Looking North: Sharpening America's Arctic Focus, Secretary of State, Rovaniemi, Finland 


\section{Christer Pursiainen, Chris Alden and Rasmus Bertelsen}

(6 May 2019), https://www.state.gov/secretary/remarks/2019/05/291512.htm (acccessed 16 Jan. 2020); X. Li and R. G. Bertelsen, "The Drivers of Chinese Arctic Interests: Political stability and energy and transportation security"; P. Stewart and I. Ali, "Pentagon Warns on Risk of Chinese Submarines in Arctic," Reuters (May 2, 2019), https:/www.reuters. com/article/us-usa-china-military-arctic/pentagon-warns-on-risk-of-chinese-submarines-inarctic-idUSKCN1S829H (accessed 1 Apr. 2020).

25. J. Hellström, China's Acquisitions in Europe. European Perceptions of Chinese Investments and their Strategic Implications (FOI-R--4384-SE, December 2016).

26. M. R. Pompeo, Speech: Looking North: Sharpening America's Arctic Focus.

27. I. Taylor, China's New Role in Africa (Boulder, CO: Lynne Rienner, 2008); see also S. Jackson, "China's Third World Foreign Policy: the case of Angola and Mozambique, 1961-93," China Quarterly 142 (1995), 388-422.

28. A. Li, H. Liu, H. Pan, A. Zeng \& W. He, FOCAC Twelve Years Later: achievements, challenges and the way forward, Discussion Paper 74 (Uppsala: Peking University/Nordiska Afrikainstitutet, 2012), http://nai.diva-portal.org/smash/get/diva2:538478/FULLTEXT01 (accessed 3 Jan. 2020) ; I. Taylor, China's New Role in Africa; D. Shinn and J. Eisenman, China and Africa: a century of engagement (Philadelphia: University of Pennsylvania Press, 2012).

29. C. Alden and M. Davies, "Chinese Multinational Corporations in Africa," South African Fournal of International Affairs 13:1 (2006), 83-96.

30. Y. I. Sun, K. Jarayam and O. Kassiri, Dance of the Lions and Dragons: How China and Africa are engaging and how the partnership will evolve (McKinsey \& Company, 2007).

31. MOFCOM, Statistics in China-Africa trade in 2018 (2019), http://english.mofcom.gov.cn/ article/statistic/lanmubb/AsiaAfrica/201901/20190102831255.shtml (accessed 3 May 2020).

32. C. Alden and L. Jiang, "Brave New World: Debt, Industrialisation and Security in ChinaAfrica Relations,” International Affairs 95:3 (2019), 641-657.

33. B. Gill and C-H. Huang, China's Expanding Role in Peacekeeping: prospects and policy implications, SIPRI Policy Paper 25 (Stockholm: Swedish Peace Research Institute, 2009), 1-37.

34. T. Headley, "China's Dibouti Base: a one year update," The Diplomat, December 4, 2018, https://thediplomat.com/2018/12/chinas-djibouti-base-a-one-year-update/ (accessed 3 Jan. 2020); E. Downs, J. Becker and P. deGategno, China's Military Support Facility in Djibouti: The Economic and Security Dimensions of China's First Overseas Base (Arlington United States: Center for Naval Analyses, 2017).

35. J.-P. Cabestan, 'China's Military Base in Diibouti: A Microcosm of China's Growing Competition with the United States and New Bipolarity,' Fournal of Contemporary China, 731-747.

36. C. Alden and L. Jiang, "Brave New World: Debt, Industrialisation and Security in ChinaAfrica Relations."

37. H. Legarda and M. Nouwens, "Guardians of the Belt and Road: the internationalisation of China's private security companies," China Monitor Mercator/IISS (2018), https://www.merics.org/en/china-monitor/guardians-of-belt-and-road (accessed 15 May 2020); O. Gafarvo, "The Rise of China's Private Armies," The World Today (February/March 2019), https://www. chathamhouse.org/publications/twt/rise-china-s-private-armies (accessed 3 Jan. 2020).

38. J. R. Bolton, Speech:The Trump Administration's New Africa Strategy. Remarks by National Security Advisor Ambassador Fohn R. Bolton (Heritage Foundation. Washington, D.C.: December 13, 2018), http://000eqb7.wcomhost.com/WordPress1/wp-content/uploads/2019/04/TheTrump-Administration-Strategy-on-Africa.pdf (accessed 3 Jan. 2020)

39. A-E. Ursu and W. van den Berg, China and the EU in the Horn of Africa: competition and cooperation? (Netherlands Institute of International Affairs, 2018), p. 9, https://www.clingendael.org/sites/default/files/2018-04/PB_China_and_the_EU_in_the_Horn_of_Africa.pdf (accessed 3 Jan. 2020). 
40. Mahan, The Influence of Sea Power Upon History. 1660-1783.

41. H. J. Mackinder, "The Geographical Pivot of History."

42. S. D. Krasner, International Regimes (Ithaca, NY: Cornell University Press, 1983); V. Rittberger, Regime Theory and International Relations (Oxford: Clarendon, 1993); R. M. A. Crawford, Regime Theory in the Post-Cold War World. Rethinking Neoliberal Approaches to International Relations (Aldershot: Dartmouth Publishing Company Ltd., 1996).

43. P. D. Tortola, "Clarifying multilevel governance," European fournal of Political Research 56 (2017), 234-250.

44. O. Young, Creating Regimes. Arctic Accords and International Governance (Ithaca and London: Cornell University Press, 1988).

45. E. W. Rowe, Arctic Governance. Power in cross- border cooperation (Manchester: Manchester University Press, 2018).

46. PRC State Council, China's Arctic Policy (White Paper).

47. Y. Sun, “The Intricacy of China's Arctic Policy," Stimson (August 27, 2018), 2, https://www. stimson.org/content/intricacy-chinas-arctic-policy (accessed 5 May 2020).

48. PRC State Council, China's Arctic Policy (White Paper).

49. T. Koivurova, L. Kauppila, S. Kopra, M. Lanteigne, M. Shi, M. Smieszek and A. Stepien, China in the Arctic and the Opportunities and Challenges for Chinese-Finnish Arctic Co-operation (Helsinki: Prime Minister's Office, Publications of the Government's analysis, assessment and research activities 8/2019, 2019), 51 .

50. Arctic Council, Arctic Council Observer Manual for Subsidiary Bodies (Tromsø, Norway: Arctic Council Secretariat, 2013); A. Chater, "Explaining Non-Arctic States in the Arctic Council," Strategic Analysis 40:3 (2016), 173-184.

51. J. Babin and F. Lasserre, "Asian states at the Arctic Council: perceptions in Western States," Polar Geography 42:3 (2019), 145-159.

52. M. Pan and H. P. Huntington, "A precautionary approach to fisheries in the Central Arctic Ocean: Policy, science, and China," Marine Policy 63, January (2016), 153-157.

53. A. N. Vylegzhanin, O. R. Young and P. A. Berkman. "The Central Arctic Ocean Fisheries Agreement as an element in the evolving Arctic Ocean governance complex," Marine Policy 118, August (2020), 104001.

54. V. J. Schatz, A. Proelss and N. Liu, "The 2018 Agreement to Prevent Unregulated High Seas Fisheries in the Central Arctic Ocean: A Critical Analysis," The International fournal of Marine and Coastal Law 34 (2019), 195-244, here p. 244.

55. PRC State Council, China's Arctic Policy (White Paper).

56. S. Yilmaz, "Exploring China's Arctic Strategy: Opportunities and Challenges," China Quarterly of International Strategic Studies Vol. 3, No. 1 (2017), 5, 6.

57. S. Kirchner, "Greening Arctic Cruise Shipping Through Law and Technology: A Role for China," in A. Bislev, U. Pram Gad and J. W. Zeuthen, eds., Special Section: China \& the Arctic, in Arctic Yearbook 2018, eds. L. Heininen et al. (Northern Research Group, 2018), $71-83$, here 77.

58. T. Koivurova et al. China in the Arctic and the Opportunities and Challenges for Chinese-Finnish Arctic Co-operation, 26.

59. A-M. Brady, China as a Polar Great Power (Cambridge: Cambridge University Press, 2017); S. Ping and M. Lanteigne, "China's Developing Arctic Policies: Myths and Misconceptions," FCIR, Vol. 3, No. 1 (2015), https://journals.aau.dk/index.php/jcir/article/view/1144 (accessed 3 Jan. 2020); S. Rainwater, "Race to the North: China's Arctic Strategy and Its Implications," Naval War College Review Vol. 66, No. 2 (2013), Article 7, https://digitalcommons.usnwc.edu/nwc-review/vol66/iss2/7 (accessed 1 June 2020); T. Koivurova et al. China in the Arctic and the Opportunities and Challenges for Chinese-Finnish Arctic Co-operation; F. Lasserre, China and the Arctic: Threat or Cooperation Potential for Canada? China Papers 


\section{Christer Pursiainen, Chris Alden and Rasmus Bertelsen}

No. 11. (Canadian International Council, 2010); M. Lanteigne, "'Have you entered the storehouses of the snow?' China as a norm entrepreneur in the Arctic," Polar Record 53, 269 (2017), 117-130.

60. M. R. Pompeo, Speech: Looking North: Sharpening America's Arctic Focus.

61. European Parliament, China's Arctic Policy. How China aligns rights and interests (European Parliamentary Research Service, May 2018), 3, http://www.europarl.europa.eu/RegData/ etudes/BRIE/2018/620231/EPRS_BRI(2018)620231_EN.pdf (accessed 3 June 2020).

62. European Commission, European Commission and HR/VP Contribution to the European Council EU-China - A Strategic Outlook, Joint Communication to the European Parliament, the European Council and the Council. JOIN (2019) 5 final. 12 March, 4, 7.

63. R. Jackson and C. Rosberg, "Sovereignty and Underdevelopment: juridical statehood in the African crisis," Fournal of Modern African Studies 24:1, (1986), 1-31.

64. J-F. Bayart, "Africa in the World: a history of extraversion," African Affairs 99:395 (2000), 217-267.

65. Diplomacy and aid in Africa, The Economist (April 14, 2016), https://www.economist.com/ graphic-detail/2016/04/14/diplomacy-and-aid-in-africa (accessed 3 June 2020); Y. Quinfu, Data Analysis: who votes with China and who votes with the US and Europe at the UN? (28 June 2018), https://yiqinfu.github.io/posts/united-nations-general-assembly/ (accessed 3 June 2020).

66. S. Van Hoeymissen, "Regional Organizations in China's Security Strategy for Africa: The Sense of Supporting 'African Solutions to African Problems'," fournal of Current Chinese Affairs, 40(4) (2011), 91-118.

67. I. Taylor,"France a Fric: the CFA zone in Africa and neo-colonialism," Third World Quarterly (2019), https://doi.org/10.1080/01436597.2019.1585183 (accessed 3 June 2020).

68. C. Alden and L. Jiang, "Brave New World: Debt, Industrialisation and Security in ChinaAfrica Relations."

69. N. Cheeseman, Democracy in Africa: successes, failures and the struggle for political reform (Cambridge: Cambridge University Press, 2019).

70. P. Chabal and J-P. Daloz, Africa Works: the Political Instrumentality of Disorder (Oxford: James Currey. 1999).

71. European Commission, European Commission and HR/VP Contribution to the European Council EU-China - A Strategic Outlook, 4, 7.

72. E.g. A. Wendt, Social Theory of International Politics (Cambridge: Cambridge University Press, 1999).

73. T. Hopf, Social Construction of International Politics: Identities and Foreign Policies, Moscow 1955 and 1999 (Ithaca, NY: Cornell University Press, 2002).

74. E.g. A. Clunan, The Social Construction of Russia's Resurgence: Aspirations, Identity and Security Interests (Baltimore: The Johns Hopkins University Press, 2009).

75. R. L. Jepperson, A. Wendt and P. J. Katzenstein, 'Norms, Identity, and Culture in National Security,' in The Culture of National Security: Norms and Identity in World Politics, ed. P. J. Katzenstein (New York: Columbia University Press, 1996), 33-75.

76. S. G. Walker, ed., Role Theory and Foreign Policy Analysis (Durham: Duke University, 1987); S. Harnish, C. Frank and H. Maull, eds., Role Theory in International Relations: Approaches and Analysis (New York: Routledge, 2011).

77. L. Jakobson and J. Peng, China's Arctic Aspirations. SIPRI Policy Paper 34 (Stockholm: Stockholm International Peace Research Institute, 2012), 22.

78. PRC State Council, China's Arctic Policy (White Paper).

79. Based on Sun's interviews, see Y. Sun, "The Intricacy of China's Arctic Policy", 2.

80. Ibid.

81. M. R. Pompeo, Speech: Looking North: Sharpening America's Arctic Focus. 
82. Foint Statement from the President of the Republic of Finland and the President of the United States (Washington D.C., October 2, 2019).

83. Arctic Council. Rovaniemi Ministerial Statements. On the Occasion of the Eleventh Ministerial meeting of the Arctic Council (2019), https://oaarchive.arctic-council.org/handle/11374/373. (accessed 3 Jan. 2020).

84. See declarations from 2000 through 2018: FOCAC, Forum on China-Africa Cooperation (n.d.), https://www.focac.org/eng/ (accessed 3 Jan. 2020).

85. FOCAC Twelve Years Later: achievements, challenges and the way forward.

86. Z. Ruinan, "African Students Set Their Sights on China," China Daily (October 10, 2018), http://www.chinadaily.com.cn/a/201810/06/WS5bb80f27a310eff303280d1e.html (4 Jan. 2020); K. King, "China will continue to back Confucius Institutes in Africa," China Daily (August 24, 2018), http://www.chinadaily.com.cn/a/201808/24/WS5b835c0aa310add14f 387e76.html (accessed 3 June 2020).

87. C. Alden and A. C. Alves, "China's Regional Forum Diplomacy in the Developing World: socialisation and the Sinosphere," Fournal of Contemporary China 26:103 (2017), 151-165.

88. European Commission, European Commission and HR/VP Contribution to the European Council EU-China - A Strategic Outlook, 4.

89. L. Hanauer, and L. J. Morris, Chinese Engagement in Africa. Drivers, Reactions, and Implications for U.S. Policy. (Rand Corporation, 2014), https://www.rand.org/content/dam/rand/ pubs/research_reports/RR500/RR521/RAND_RR521.pdf (accessed 3 June 2020); S. Li and H. Rønning, H., China in Africa: Soft power, media perceptions and a pan-developing identity. (CMI Report, 2013), https://www.cmi.no/publications/4943-china-in-africa-soft-power (accessed 3 June 2020).

90. R. G. Bertelsen, L. Xing and M. H. Gregersen."Chinese Arctic science diplomacy. An instrument for achieving the Chinese Dream," in Global Challenges in the Arctic Region: Sovereignty, environment and geopolitical balance, eds. Elena Conde and Sara Iglesias Sánchez (London: Routledge, 2017), 442-460. 